\title{
Prognostic Analysis of Neutrophil/Lymphocyte Ratio and Thrombocyte/Lymphocyte Value Before Trimodal Treatment in Invasive Bladder Cancer
}

\section{İnvaziv Mesane Kanserinde Trimodal Tedavi Öncesinde Nötrofil/Lenfosit Oranı ve Trombosit/Lenfosit Değerinin Prognostik Önemi}

(1) Berrin İnanç, (1) Özlem Mermut

University of Health Sciences Turkey, İstanbul Training and Research Hospital, Clinic of Radiation Oncology, İstanbul, Turkey

\begin{abstract}
Introduction: To evaluate whether neutrophil/lymphocyte (NLR) and platelet/lymphocyte (PLR) ratios have prognostic value in patients undergoing bladder conserving treatment (trimodal therapy)

Methods: A total of 40 patients receiving trimodality treatment for invasive bladder cancer were included in the study retrospectively. NLR and PLR were obtained for every patient before trimodality treatment was applied. We investigated whether NLR and PLR values had prognostic value for survival.

Results: Gender, age, T stage, Histologic grade, radiotherapy dose, NLR and PLR values were evaluated in bladder cancer patients receiving trimodal therapy. In the receiver operating characteristic analysis, the optimum cut-off value for NLR was found to be 3.2 (sensitivity $71.4 \%$, specificity $65.2 \% p<0.025$ ). Area under the curve (AUC): 0.717 , confidence interval (CI) 95\% (0.557-0.877), the optimum cut-off for PLR was found as 152.25 (sensitivity $78.1 \%$, specificity $64.2 \%, p<0.006$ ), AUC: $0.764, \mathrm{Cl}$ $95 \%$ (0.610-0.917). Survival analysis showed that disease-free survival was $52.36 \pm 6$ months and statistically significant in patients with an NLR value greater than $3.2(p=0.023)$. PLR value above 152.25 was found to be an independent risk factor for disease-free survival (52.8 \pm 6.1 months) and overall survival (50.6 \pm 7.2 months) ( $p=0.043, p=0.011$, respectively).
\end{abstract}

Conlusion: NLR and PLR before trimodal treatment in invasive bladder cancer patients may be considered as a prognostic factor for disease progression. NLR and PLR values should be taken into consideration when deciding on trimodal treatment.

Keywords: Bladder cancer, chemoradiotherapy, neutrophil/ lymphocyte ratio, platelet/lymphocyte ratio

\section{öZ}

Amaç: Mesane koruyucu tedavi (trimodal tedavi) uygulanan hastalarda nötrofil/lenfosit (NLR) ve trombosit/lenfosit (PLR) oranının prognostik bir değerinin olup olmadığını değerlendirdik.

Yöntemler: Bu retrospektif çalıșmaya kasa invaze mesane kanseri tanısı alan ve trimodal (TUR + kemoradyoterapi) tedavi uygulanan 40 hasta dahil edildi. Trimodal tedavi uygulanmadan önce NLR ve PLR kan değerlerinden elde edildi. NLR ve PLR değerlerinin sağkalım açısından prognostik değeri olup olmadığı araştırıldı.

Bulgular: Trimodal tedavi alan mesane kanserli hastalarda, cinsiyet, yaș, T evresi, radyoterapi dozu, NLR ve PLR değerleri değerlendirildi. Alıcı işletim karakteristiği analizinde NLR için, optimum cut-off değeri 3,2 olarak bulundu. (sensitivite $\% 71,4$, spesifite $\% 65,2 p<0,025)$. Eğri altındaki alan (AUC): 0,717, güven aralığı (Cl): \%95 (0,557-0,877), PLR için optimum cut-off 152,25 olarak bulundu (sensitivite \%78,1, spesifite $\% 64,2, p<0,006)$. AUC: $0,764, \mathrm{Cl}: \% 95(0,610-0,917)$. Sağkalım analizlerinde NLR değeri 3,2 üzerinde olan hastalarda hastalıksız sağkalım $52,3 \pm 6$ ay ve istatiksel olarak anlamlıydı $(p=0,023)$. PLR değerinin 152,25 üzerinde olması hastalıksız

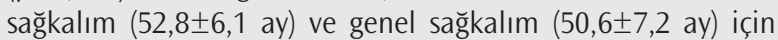
bağımsız bir risk faktörü olarak bulundu ve istatiksel olarak anlamlıydı (sırasıyla $p=0,043, p=0,011$ ).

Sonuç: Invaziv mesane kanserli hastalarda trimodal tedavi öncesinde NLR ve PLR değeri hastalık progresyonunu göstermek için prognostik bir faktör olarak değerlendirilebilir. Trimodal tedavi kararı verilirken NLR ve PLR değerleri de göz önünde bulundurulmalıdır.

Anahtar Kelimeler: Mesane kanseri, kemoradyoterapi, nötrofil/lenfosit oranı, trombosit/lenfosit oranı

Cite this article as/Atıf: İnanç B, Mermut Ö. Prognostic Analysis of Neutrophil/Lymphocyte Ratio and Thrombocyte/Lymphocyte Value Before Trimodal Treatment in Invasive Bladder Cancer. İstanbul Med J 2020; 21(2): 82-7.

(c) Copyright 2020 by the University of Health Sciences Turkey, Istanbul Training and Research Hospital/istanbul Medical Journal published by Galenos Publishing House.

(C) Telif Hakkı 2020 Să̆lık Bilimleri Üniversitesi istanbul Ĕgitim ve Araștırma Hastanesi/Istanbul Tıp Dergisi, Galenos Yayınevi tarafından basılmıștır. 


\section{Introduction}

Invasive bladder cancer accounts for about $30 \%$ of all bladder cancers. In invasive bladder cancers, advanced treatment is needed after transurethral resection (TUR); in very rare cases, TUR is sufficient $(1,2)$. These treatment regimens include radical cystectomy, partial cystectomy, bladder protective approaches and systemic treatments in advanced stage patients. Bladder protective treatments come to the forefront for patients who avoid radical surgical treatments due to the continuation of the patient's quality of life and maintaining organ function. With treatment applications (trimodality) including maximum TUR, radiotherapy (RT) and chemotherapy $(\mathrm{CT})$, results similar to radical surgery are obtained in the treatment of invasive bladder cancer. In order to apply bladder protective treatment, the absence of small tumor $(<5 \mathrm{~cm})$, single focus disease, microscopic full TUR (R0-1), urethral obstruction or hydronephrosis, and the absence of pelvic lymph node metastasis and no reported in situ carcinoma are required.

It is known today that inflammation plays a critical role in the emergence, progression and metastasis of the tumor (3). While neutrophil count increases during systemic inflammation, neutrophil/lymphocyte (NLR) ratio and platelet/lymphocyte $(P L R)$ ratio change with decreasing Iymphocyte count. There are many studies suggesting that the rate of NLR is an effective predictive marker in many cancers $(4,5)$ and bladder cancer $(6,7)$. However, to date, there is no study investigating the rate of NLR and PLR rates together before trimodal treatment in patients with invasive bladder cancer.

In this study, we tried to reveal that NLR and PLR are a prognostic marker before the selection of trimodal treatment for invasive bladder cancer.

\section{Methods}

We retrospectively evaluated 52 patients who were diagnosed with invasive bladder cancer after TUR, who were not eligible for radical surgical intervention or who did not want it, or who were sent to University of Health Sciences Turkey, İstanbul Training and Research Hospital, Deparment of Radiation Oncology for bladder protective treatment between 2011 and 2018. While all relevant laboratory and pathology results were obtained from the hospital data, the data related to treatment follow-up were obtained from the clinical files. The recurrence and progression status for each patient was determined from these patient files.

Patients who were not eligible for bladder protective treatment (patients with the presence of carcinoma in situ, tumors larger than $5 \mathrm{~cm}$, hydronephrosis, and pelvic lymph node metastasis, patients not undergoing microscopic full urethral resection) and those with any malignancy except bladder tumor, acute inflammatory diseases, bleeding disorders, and hematological disorders were excluded from the study after TUR. Of the 52 patients examined, we selected a total of 40 patients with clinically T2-T4a tumors after TUR. These patients received chemoradiotherapy after maximal TUR, and NLR and PLR ratios were determined from blood tests prior to the treatment.

The relationships between the patients' gender, age, $T$ stage of the tumor, dose of RT, total follow-up time, overall survival and diseasefree survival (regional and/or distant metastasis) times and NLR and PLR rates were examined.
Approval for this study was obtained from the Ethics Committee of University of Health Sciences Turkey, İstanbul Training and Research Hospital (decision no: 12-04-2019/1792).

\section{TUR and Chemotherapy Data}

All patients received maximal TUR and then chemoradiotherapy. RT protocols; with a daily dose of 1.8-2 Gy/fraction, pelvic lymph nodes were sometimes included, and after 40-45Gy, it was applied to the bladder or tumor as to increase $65 \mathrm{~Gy}$. The CT protocol of Cisplatin 35 $\mathrm{mg} / \mathrm{m}^{2}$ was applied weekly by the Medical Oncology Clinic. Patients were evaluated for acute toxicity every 10 days.

\section{Blood Tests}

Blood test results of a total of 40 patients who were eligible for trimodal treatment were examined before routine treatment. The data obtained included neutrophil count, lymphocyte count, and platelet count. NLR was determined by dividing absolute neutrophil count by absolute lymphocyte count and PLR was determined by dividing absolute platelet count by absolute lymphocyte count.

\section{Statistical Analysis}

Statistical analyses were performed using IBM SPSS version 18.0 for Windows. Receiver operating characteristic (ROC) analysis was performed to determine the cut-off values of the NLR and PLR values. Survival analyses were performed using the Kaplan Meier method. Log-rank test was used in univariate analyses. $\mathrm{P}<0.05$ was considered statistically significant.

\section{Results}

Of the total 40 patients we included in the study, 5 were women and 35 were men. The mean follow-up period was 26 (5-72) months.

In almost all patients, the first complaint was hematuria. Their histopathologies were transitional epithelial cell carcinoma. Gender distribution, age distribution, hemoglobin values, T stage, RT doses, and the number of patients above and below the cut-off values of NLR and PLR are summarized in Table 1.

In univariate analysis, patients' being at T2 stage was found to be a prognostic value for overall survival $(p=0.003)$.

In ROC analysis, optimum cut-off value for NLR was found to be 3.2 (Figure 1) (sensitivity $71.4 \%$, specificity $65.2 \% p<0.025$ ), Area under the curve (AUC): 0.717 , confidence interval (CI): 95\% (0.557-0.877). Local recurrence and metastasis were detected in 11 patients with a NLR value greater than 3.2, while local recurrence and metastasis were not detected in 9 patients. In the univariate analysis, disease-free survival was $52.3 \pm 6$ months. While there were metastases and local recurrence in 3 patients with an NLR value below 3.2, no local recurrence and metastasis was detected in 17 patients with a value under 3.2. In this group of patients, disease-free survival was $27.6 \pm 6.6$ months, which was statistically significant $(p=0.023)$. While overall survival was $52 \pm 14.1$ months in patients with an NLR value above 3.2 , it was $14 \pm 2.08$ months in patients with an NLR below 3.2, and this was not statistically significant $(p=0.075)$ (Figure 3 and Table 2). 
In the ROC analysis, the optimum cut-off for PLR was found to be 152.25 (Figure 2) (78.1\% in sensitivity, $64.2 \%$ in specificity, $p<0.006)$, AUC: 0.764 , Cl: 95\% (0.610-0.917). Local recurrence and metastasis were detected in 11 patients with PLR value above 152.25, while local recurrence and metastasis were not detected in 12 patients. Disease-free survival was $52.8 \pm 6.1$ months in univariate analysis. Local recurrence and metastasis were detected in 3 patients with PLR below 152.25, whereas local recurrence and metastasis were not detected in 14 patients. In this

Table 1. General and treatment features of the patients

\begin{tabular}{|c|c|c|}
\hline & $\begin{array}{l}n=40 \text { (number of } \\
\text { patients) }\end{array}$ & $\%$ \\
\hline Female & 5 & 12.5 \\
\hline Male & 35 & 87.5 \\
\hline Age (mean $\pm S D$ ) & $64 \pm 6.5(50-76)$ & \\
\hline Under the age of 65 years & 21 & 52.5 \\
\hline Above the age of 65 years & 19 & 47.5 \\
\hline \multicolumn{3}{|l|}{ Stage } \\
\hline $\mathrm{T} 2$ & 33 & 82.5 \\
\hline T3 & 4 & 10 \\
\hline T4 & 3 & 7.5 \\
\hline \multicolumn{3}{|l|}{ RT dose } \\
\hline $60 \mathrm{~Gy}$ & 4 & 10 \\
\hline $66 \mathrm{~Gy}$ & 36 & 90 \\
\hline Hemoglobin value (mean \pm SD) & $11.9 \pm 1.97(7.6-16)$ & \\
\hline \multicolumn{3}{|l|}{ NLR } \\
\hline$\geq 3.2$ & 21 & 52.5 \\
\hline$\leq 3.2$ & 19 & 47.5 \\
\hline \multicolumn{3}{|l|}{ PLR } \\
\hline$\geq 152.25$ & 23 & 42.5 \\
\hline$\leq 152.25$ & 17 & 57.5 \\
\hline Disease-free survival & $21.10(3-66)$ & \\
\hline Overall survival & $26.75(5-72)$ & \\
\hline
\end{tabular}

SD: standard deviation, RT: radiotherapy, NLR: neutrophil/lymphocyte, PLR: platelet/ lymphocyte

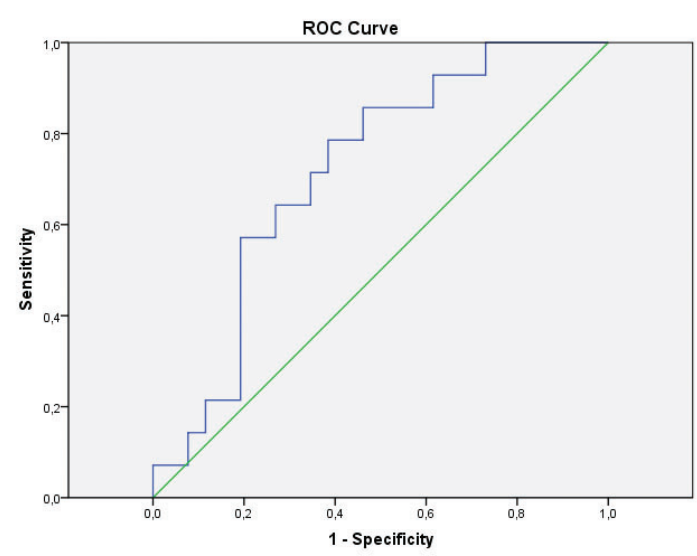

Figure 1. ROC Curve Analysis to determine the cut-off value of neutrophil/ lymphocyte

ROC: Receiver operating characteristic

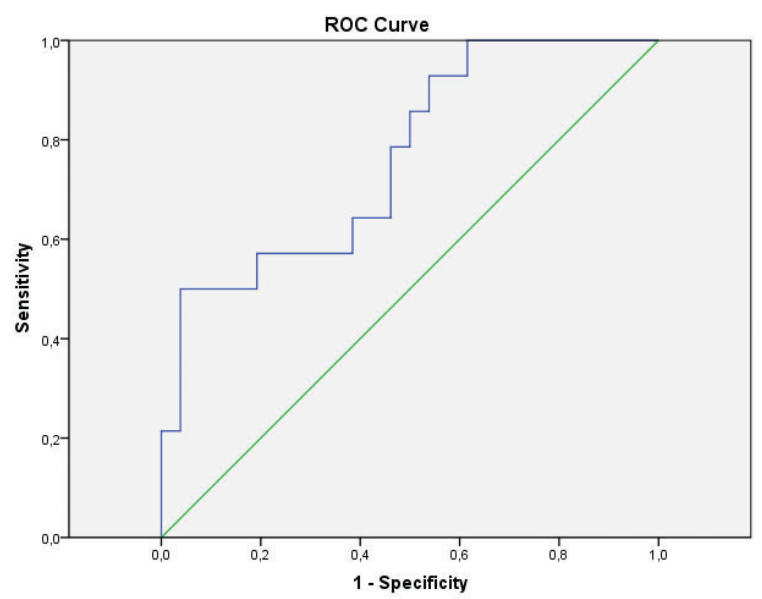

Figure 2. ROC Curve Analysis ROC Curve Analysis to determine the cut-off value of platelet/lymphocyte

ROC: Receiver operating characteristic
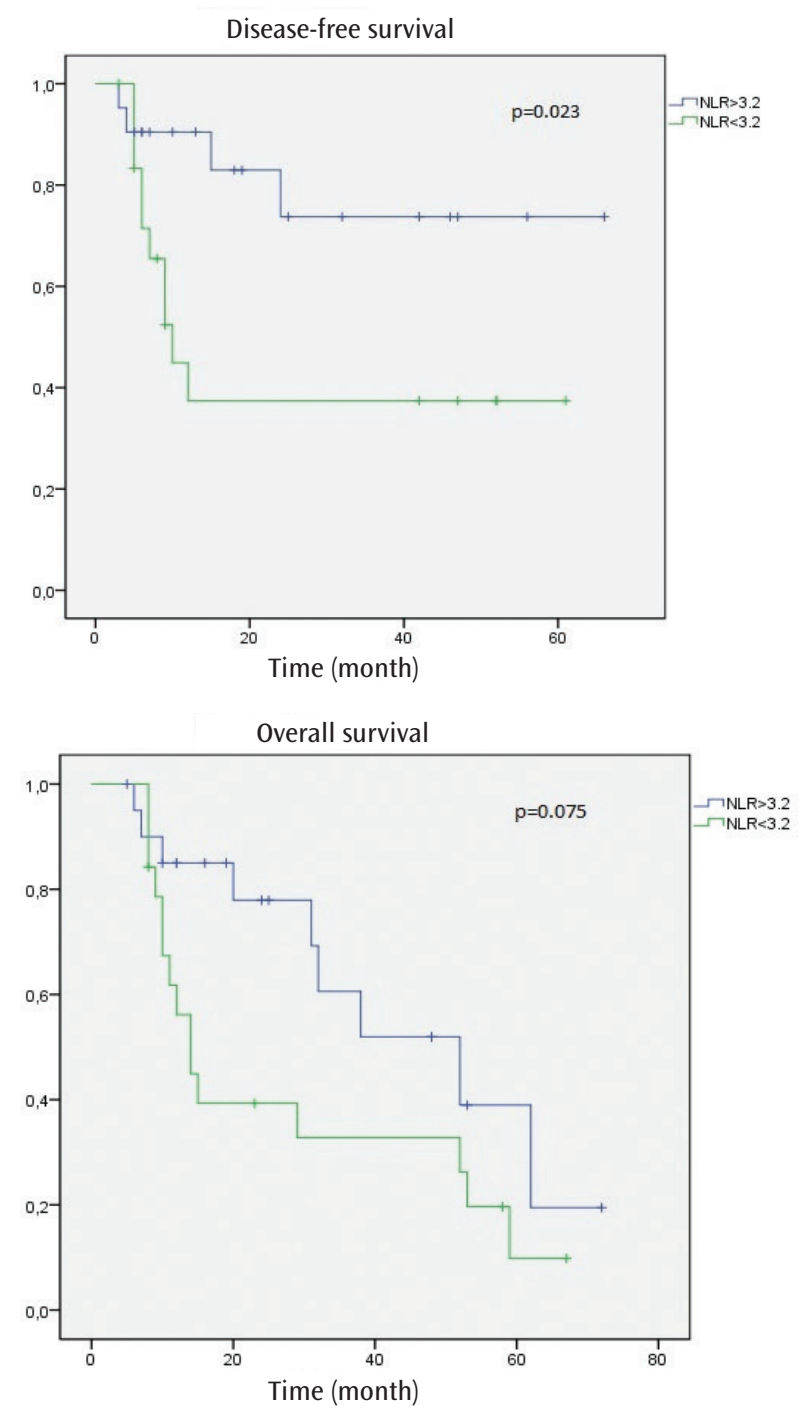

Figure 3. Kaplan-Meier curves for disease-free and overall survivals for neutrophil/lymphocyte value

NLR: neutrophil/lymphocyte 
patient group, disease-free survival was $31.2 \pm 6.7$ months and this was found to be statistically significant $(p=0.043)$. While overall survival was 50.6 \pm 7.2 months in patients with a PLR value above 152.25, it was $27.5 \pm 4.4$ months in patients with a PLR value below 152.25 , and this was statistically significant ( $p=0.011$ ) (Figure 4 and Table 2).

\section{Discussion}

In muscle-invasive bladder cancers, it is more common in men than in women, and patients receiving trimodal treatment are generally male patients (8). Similarly in our study, 35 patients were male and 5 were female. Bladder cancers can occur in any age group, but its frequency increases with age. It occurs around the age of 69 years in men and around the age of 71 years in women. Although it has a good prognosis

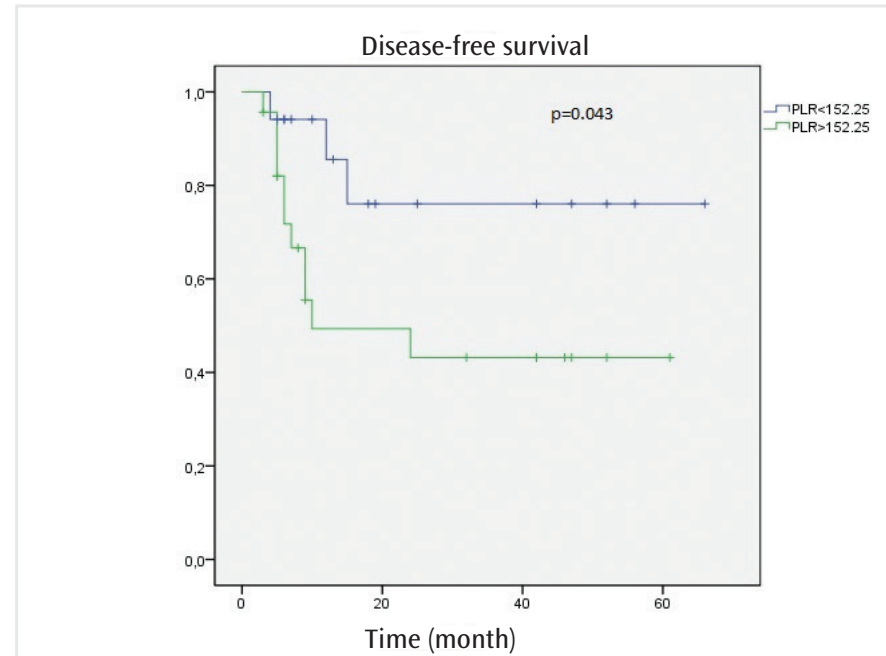

in patients under 40 years of age, it is more aggressive in elderly patients (9). In our study, the mean age was found to be $65 \pm 6.5$ (50-76) years and this was compatible with literature (9). While 21 of the patients were below the age of 65 years, 19 were above the age of 65 years. Pathological stage of the tumor in bladder cancer is the most important factor in determining its treatment. While TUR is sufficient in nonmuscle invasive tumors, intravesical treatments are applied to reduce regional recurrence. In patients with muscle-invasive bladder cancer, trimodal treatment is usually used after the $\mathrm{T} 2$ stage. When we consider our study, while there were patients with 12 tumors (33 patients), 4 patients with $\mathrm{T} 3$ and 3 patients with $\mathrm{T} 4$ tumors were present. It is known that prognosis and overall survival in early stage tumors are good. In our study, overall survival was better in the $\mathrm{T} 2$ stage and this was statistically significant $(p=0.003)$.

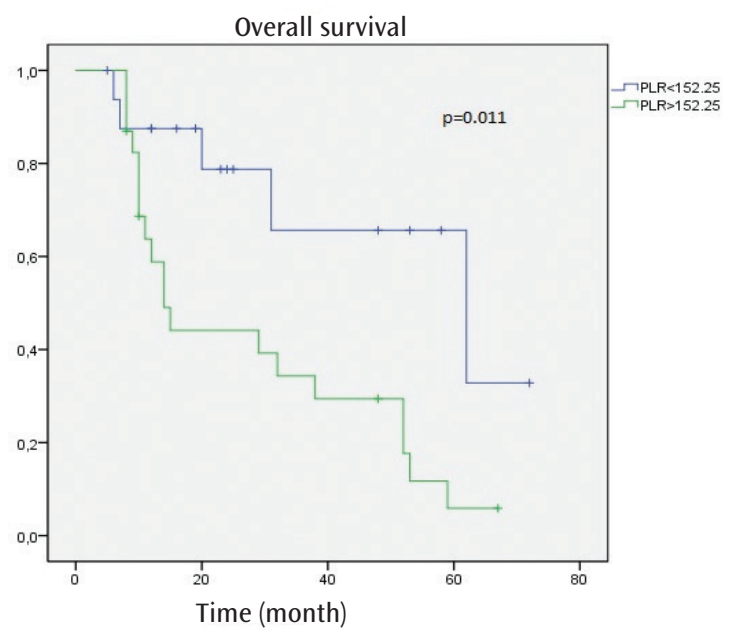

Figure 4. Kaplan-Meier curves for disease-free and overall survivals for platelet/lymphocyte value

PLR: platelet/lymphocyte

Table 2. Prognostic factors for disease-free survival and overall survival

\begin{tabular}{|c|c|c|c|c|c|c|}
\hline & & $\begin{array}{l}\text { Number of } \\
\text { patients }\end{array}$ & $\begin{array}{l}\text { Disease-free survival } \\
\text { (month) }\end{array}$ & $p$ & $\begin{array}{l}\text { Overall survival } \\
\text { (month) }\end{array}$ & $p$ \\
\hline Gender & Female & 5 & $23.2 \pm 9$ & 0.285 & $29 \pm 10$ & 0.121 \\
\hline \multirow{2}{*}{ Age } & Under the age of 65 years & 21 & $35 \pm 6$ & 0.512 & $31 \pm 7$ & 0.906 \\
\hline & Above the age of 65 years & 19 & $46 \pm 7$ & - & $52 \pm 27$ & - \\
\hline \multirow[t]{2}{*}{ Stage } & T3 & 4 & $6 \pm 2.02$ & - & $8 \pm 1.5$ & - \\
\hline & $\mathrm{T} 4$ & 3 & - & - & - & - \\
\hline \multirow{2}{*}{ Dose of radiotherapy } & 60 Gy & 4 & $38.5 \pm 4.8$ & 0.863 & $35 \pm 4.0$ & 0.762 \\
\hline & $66 \mathrm{~Gy}$ & 36 & $51.0 \pm 12.9$ & & $40 \pm 15.7$ & - \\
\hline NLR & $\geq 3.2$ & 21 & 52.3 & 0.023 & $52 \pm 14.1$ & 0.075 \\
\hline \multirow{2}{*}{ Final status } & Alive & 24 & - & - & - & - \\
\hline & Ex & 16 & - & - & - & - \\
\hline
\end{tabular}


RT dose is 60-66 Gy in patients with bladder cancer who receive trimodal treatment, and cisplatin or 5-Flurouracil is used as a radiosensitizer (10). In our study, cisplatin $35 \mathrm{mgr} / \mathrm{m}^{2}$ was given weekly to all patients. Systemic CT was not applied weekly to some patients due to acute hematologic and gastrointestinal toxicity.

As a TR dose, 60 Gy was applied only in 4 patients, and in the remaining 36 patients, 66 Gy RT was applied externally (Table 1).

While non-invasive bladder cancers often recur after TUR, invasive bladder cancers and high grade tumors tend to make distant metastases. The regional recurrence and distant metastasis of the tumor depends on the characteristics of the tumor cell and the environmental conditions of the tumor (11). The presence of tumor cells and the behaviors of tumor cells, compared to normal cells, cause inflammatory reactions in the tissues surrounding the tumor. These inflammatory reactions cause an increase in the number of white blood cells in the bloodstream (12). There are many parameters to evaluate the systemic inflammatory response in peripheral blood tests. White blood counts consisting of fibrinogen, ferritin, albumin, C-reactive protein, transferrin, lymphocyte and neutrophil in the blood are examples for them.

There is growing evidence to support that systemic inflammation contributes to cancer development and progression (13). O'Toole et al. (14) reported that the increase in lymphocyte activity against bladder cancer tumor cells was associated with the clinical stage. In the peripheral blood count, the NLR value obtained by dividing the absolute neutrophil count by the lymphocyte count has been evaluated in many studies and its relationship with the recurrence of some types of cancer has been examined $(15,16,17)$. Considering the studies in the literature, a cut-off value of NLR was determined for each cancer type and it was observed that recurrence was more frequent in patients over this value $(15,16,17,18)$.

In our study, the cut-off value for NLR was found to be 3.2. While regional recurrence and distant metastasis were detected in 11 patients above this value, only 3 of the patients who were below this value had regional recurrence and distant metastasis. Disease-free survival was $52 \pm 3.0$ months in patients with an NLR value above 3.2 , while it was found to be $27.6 \pm 6.6$ months in patients with a NLR value below 3.2, which was statistically significant $(p=0.023)$

NLR value was used in many studies and its relationship with regional recurrence was shown. However, our patients were high grade patients diagnosed with invasive bladder cancer. Even if trimodal therapy or radical cystectomy was performed in these patients, the major problem was the occurrence of distant metastases. Many studies have shown that platelets play an important role in the metastatic process (19). Todenhöfer et al. (20) showed that increasing number of platelets before radical cystectomy is a bad prognostic factor. For this reason, we also examined the PLR value to evaluate distant metastasis. The PLR value is obtained by dividing the platelet count in the blood by the lymphocyte count. We found our cut-off value for PLR to be 152.25. While 11 patients above this value had regional or distant metastases, 3 patients below this value did not have regional or distant metastases.

In patients with an NPLR value above 152.25, disease-free survival was $52.8 \pm 6.1$ months and overall survival was $50.6 \pm 7.2$ months. On the other hand, in patients with PLR value below 152.25, disease-free survival was $31.2 \pm 6.7$ months and overall survival was $27.5 \pm 4.4$, and this was statistically significant ( $p=0.043, p=0.011$, respectively).

In the literature, studies with NLR have generally been found to be about non-invasive bladder cancer and they have shown that the NLR value may be a prognostic factor for regional recurrence (21). Studies examining the PLR value were generally performed about stomach, brain and colon cancer (22), and invasive bladder cancer was studied in very few studies.

Contrary to all the studies, we examined the PLR value in this study and included patients who received trimodal treatment for invasive bladder cancer. When considered from this point of view, it is the only study.

In the univariate log-rank analysis performed for patients above the cutoff values of NLR and PLR, NLR value is showed to be an independent prognostic factor for disease-free survival, while PLR can be a prognostic marker for both disease-free survival and overall survival.

The low number of patients in our study may be due to the lower number of patients receiving trimodal treatment in bladder cancer compared to radical cystectomy.

\section{Conclusion}

In patients with invasive bladder cancer, while NLR and PLR values can be used as a prognostic factor to show disease progression before trimodal treatment, further pathogenic and cytogenetic studies involving more patients are needed to use NLR and PLR as a prognostic marker for overall survival.

\section{Ethics}

Ethics Committee Approval: Approval for this study was obtained from the Ethics Committee of University of Health Sciences Turkey, İstanbul Training and Research Hospital (decision no: 12-04-2019/1792).

Informed Consent: A total of 40 patients receiving trimodality treatment for invasive bladder cancer were included in the study retrospectively.

Peer-review: Externally peer-review.

Author Contributions: Concept - B.i.; Design - B.i.; Data Collection and/ or Processing - B.I.., Ö.M.; Analysis and/or Interpretation - B.İ., Ö.M.; Literature Search - B.ì., Ö.M.; Writing Manuscript - B.í.

Conflict of Interest: No conflict of interest was declared by the authors.

Financial Disclosure: The authors declared that this study received no financial support.

\section{References}

1. Solsona E, Iborra I, Collado A, Rubio-Briones J, Casanova J, Calatrava A. Feasibility of radical transurethral resection as monotherapy for selected patients with muscle invasive bladder cancer. J Urol 2010; 184: 475-80.

2. Leibovici D, Kassouf W, Pisters LL, Pettaway CA, Wu X, Dinney CP, et al. Organ preservation for muscle-invasive bladder cancer by transurethral resection. Urology 2007; 70: 473-6.

3. Herszényi L, Lakatos G, Hritz I, Varga M.Z, Cierny G,Tulassay Z. The role of inflam mation and proteinases in tumor progression. Dig Dis 2012; 30: 249 54. 
4. Jaramillo-Reta KY, Velázquez-Dohorn ME, Medina-Franco H. Neutrophil to lymphocyte ratio as predictor of surgi- cal mortality and survival in complex surgery of the upper gas- trointestinal tract. Rev Invest Clin 2015; 67: 117-21.

5. Cho H, Hur HW, Kim SW,Kim SH, Kim JH, Kim YT, et al. Pre-treatment neutrophil to lymphocyte ratio is elevated in epithelial ovarian cancer and predicts survival after treatment. Cancer Immunol Immunother 2009; 58: 1523.

6. Mano R, Baniel J, Shoshany O, Margel D, Bar-On T, Nativ O, et al. Neutrophil -to- lymphocyte ratio predicts progression and recurrence of non- muscleinvasive bladder cancer. Urol Oncol 2015; 33: 67.e1-7.

7. Krane LS, Richards KA, Kader AK, Davis R, Balaji KC, Hemal AK. Preopera- tive neutrophil/lymphocyte ratio predicts overall survival and extravesical disease in patients undergoing radical cystec- tomy. J Endourol 2013; 27: 1046-50.

8. Jemal A, Murray T, Ward E, Samuels A, Tiwari RC, Ghafoor A, et al. Cancer statistics, 2005. CA Cancer J Clin 2005; 55: 10- 30

9. Madeb R, Messing EM. Gender, racial and age differences in bladder cancer incidence and mortality. Urol Oncol 2004; 22: 86-92.

10. Mak RH, Zietman AL, Heney NM, Kaufman DS, Shipley WU. Bladder preservation: optimizing radiotherapy and integrated treatment strategies. BJU Int 2008; 102: 1345-53.

11. Totterman TH, Loskog A, Essand M: The immunotherapy of prostate and bladder can- cer. BJU Int 2005; 96: 728-35.

12. Yamada H, Luo $\mathrm{Y}$, Matsumoto $\mathrm{T}$, O'Donnel M. A novel expression of macrophage derived chemo- kine in human bladder cancer. J Urol 2005; 173 : 990-5.

13. Mantovani A, Allavena P, Sica A, Balkwill F. Cancer related inflammation. Nature 2008; 454: 436-44

14. O'Toole C, Perlman P, Unsgaard B, Moberger G, Edsmyr F. Celllular immunity to human urinary bladder carcinoma. Correlation to clinical stage and radiotherapy. Int J Cancer 1972; 10: 77-91.
15. Motomura T, Shirabe K, Mano $\mathrm{Y}$, Muto J, Toshima $\mathrm{T}$, Umemoto $\mathrm{Y}$, et al. Neutrophil-lymphocyte ratio reflects hepatocellular carcinoma recurrence after liver transplantation via inflammatory microenvironment. J Hepatol 2013; 58: 58-64.

16. Sejima $\mathrm{T}$, Iwamoto $\mathrm{H}$, Morizane $\mathrm{S}$, Hinata $\mathrm{N}$, Yao A, Isoyama $\mathrm{T}$, et al.The significant immunological characteristics of peripheral blood neutrophilto-lymphocyte ratio and Fas ligand expression incidence in nephrectomized tumor in late recurrence from renal cell carcinoma. Urol Oncol 2013; 31: 1343-9.

17. Mallappa S, Sinha A, Gupta S, Chadwick SJ. Preoperative neutrophil to lymphocyte ratio $>5$ is a prognostic factor for recurrent colorectal cancer. Colorectal Dis 2013; 15: 323-8.

18. Ohno Y, Nakashima J, Ohori M Gondo T, Hatano T, Tachibana M: Followup of neutrophil-to-lymphocyte ratio and recurrence of clear cell renal cell carcinoma. J Urol 2012; 187: 411-7.

19. Nieswandt B, Hafner M, Echtenacher B, Mannel DN: Lysis of tumor cells by natural killer cells in mice is impeded by platelets. Cancer Res 1999; 59: 1295-300.

20. Todenhöfer T, Renninger M, Schwentner C Stenzl A, Gakis G. A new prognostic model for cancer-spe- cific survival after radical cystectomy in- cluding pretreatment thrombocytosis and standard pathological risk factors. BJU Int 2012; 110: 533-40.

21. Ceylan C, Doluoglu OG, Keles I,Gazel E, Temucin T, Odabas O, et al. Importance of the neutrophil-to-lymphocyte ratio in muscle- invasive and non-muscle invasive bladder tumors. Urologia 2014; 81: 120-4.

22. Aldemir MN, Turkeli M, Simsek M, Yildirim N, Bilen $\mathrm{Y}$, Yetimoglu $\mathrm{H}$, et al. Prognostic Value of Baseline Neutrophil-Lymphocyte and PlateletLymphocyte Ratios in Local and Advanced Gastric Cancer Patients. Asian Pac J Cancer Prev 2015; 16: 5933-7. 